\title{
Using on-line analyzers and RAC parameters to determine the amount of TN and TP pollutants discharged from Poland into the Baltic Sea
}

\author{
Paweł Wilk, Adam Grabarczyk \\ Institute of Meteorology and Water Management, Section of Modeling Surface Water Quality; \\ ul.Podleśna 61,01-673 Warsaw, Poland; e-mail:Pawel.Wilk@imgw.pl
}

(C) 2018 Authors. This is an open access publication, which can be used, distributed and reproduced in any medium according to the Creative Commons CC-BY 4.0 License requiring that the original work has been properly cited.

Received: 18 December 2017; accepted: 4 April 2018

\begin{abstract}
Despite the numerous measures taken to protect its environment for many years, Poland is among the top countries with the largest contributing share in the pollution of the Baltic Sea. It is undoubtedly the case that we are dealing with excesses in the permissible concentrations of total nitrogen (TN) and total phosphorus (TP) on many sections of Polish rivers. However, in order to be able to thoroughly analyze this problem, it is first necessary to increase the frequency of TN and TP monitoring in surface waters. The article presents the first results obtained from the TN and TP monitoring system launched in 2016 at the IMGW-PIB on the calculation profile Szczecin (the Odra River) and Tczew (the Vistula River). The on-line analyzers installed for this purpose make it possible to perform measurements several times a day, allowing for the assessment of diurnal and seasonal variations of TN and TP. Using the results obtained, the daily values of the River Absorption Capacity (RAC) parameter were also calculated. The obtained results showed that, in general, the value of the RAC parameter on the analyzed calculation profiles was positive for both TN and TP throughout the entire period, irrespective of the time of year.
\end{abstract}

Keywords: Total Nitrogen (TN), Total Phosphorus (TP), surface water monitoring, River Absorption Capacity (RAC)

\section{INTRODUCTION}

By the second half of the twentieth century, it was believed that the seas and oceans are able to accept an almost unlimited amount of pollution. Reality, however, quickly disproved these assumptions. A combination of dynamically developing industry and the intensification of agriculture resulted in the entry of huge amounts of biogenic compounds into rivers and, subsequently, seas and oceans. This in turn resulted in eutrophication on an unprecedented scale (Andrulewicz 2000, Smith at al. 2016, Andersen at al. 2017). The identification of this problem initiated a period of intensified research aimed at broadening the state of knowledge about biogenic compounds and the phenomenon of eutrophication. A Helsinki Commission was established, called HELCOM, associating states that have been involved in the pollution of the Baltic Sea and coordinating new action programs aimed at limiting the inflow of nutrients into the sea (Sapek 2008, Ahtiainen at al. 2014, Tynkkynen at al. 2014, HELCOM 2015).

At the same time, there was a need to create new tools and methods that would be able to analyze the circulation and spread of pollutants in catchments in a more comprehensive manner, which led to the rapid development of environmental 
mathematical models (Ahn \& Kim 2017, Ji 2017). After Poland's accession to the EU, the need to reduce the amount of nutrients in surface waters has become one of the main tasks of water management. Despite numerous investments and the passage of years, Poland is still mentioned as one of the countries with the largest share in pollution of the Baltic Sea (Kundzewicz 2001, Rovira \& Pardo 2006, Kiedrzyńska at al. 2014). In 2012, the Makromodel DNS/SWAT was developed at the Institute of Meteorology and Water Management (IMGW-PIB) (Ostojski 2012, Ostojski at al. 2016). It takes into account a whole range of phenomena and processes taking place in the catchment such as meteorology, water erosion, surface and subsurface run-off, changes of pollutants in the environment or self-purification of waters having a direct or indirect impact on the nutrient cycle in the catchment. This makes it one of the most advanced environmental models (Abbaspour at al. 2015). The high level of detail of the model also enables the development of scenarios to answer the question "what would happen if...?" concerning changes in the use of the basin or climate change. This model has become, among other things, the basis for the development of the River Absorption Capacity (RAC) calculation method, which has been successfully applied to the Middle Warta catchment (Wilk 2015).

However, it must be remembered that even the most accurate and advanced model depends on the monitoring data necessary for its calibration and validation. Without an appropriate monitoring database, the models become worthless and their further development and refinement will not bring any results or bring us closer to the goal of pure rivers which are free of excess nutrients.

The State Environmental Monitoring (SEM) is the main source of information about the environment. This information is derived from measurements of environmental elements specially designed for this purpose, as well as evaluations based on these measurements, including, among others, control of compliance with certain environmental quality standards regulated by national and international regulations (Loga 2016).

In practice, data from SEM allow for a high level of generality to analyze the state of surface waters over a period of many years. The frequency of sampling for testing by SEM is from 6 to 12 times a year. This amount of data does not provide an opportunity to analyze the variability of diurnal and seasonal nutrient concentrations on selected calculation profiles. Therefore, already at the stage of calibration, there are problems with the correct adjustment of the model to the actual data. Research conducted at IMGW-PIB (Wilk at al. 2016, Wilk at al. 2017a) indicates that biogenic compounds, especially Total Phosphorus (TP) which comes mainly from point sources, are characterized by very high diurnal and seasonal variability, meaning that the calibration of the model based on the results of measurements performed a few or several times a year can generate very large errors.

In order to limit the above-mentioned errors in 2015, IMGW-PIB decided to extend the current TN and TP monitoring system by launching a 5-year program under which fully automated on-line analyzers were installed on the Odra and Vistula estuary profiles. One of the main advantages of such a solution is the possibility of monitoring the outflow of nutrients to the Baltic Sea on the basis of determinations carried out several times a day.

\section{MATERIALS AND METHODS}

\section{On-line analyzers}

Two Envag online analyzers were provided for the nutrient program. These devices measure the mean TN using the differential method. The nitrogenous substances introduced into the ceramic reactor are oxidized to $\mathrm{NO}_{\mathrm{x}}$ and fed with the carrier gas into the chemiluminescence detector. TP is determined in the photometric module using the Molybdenum blue method and requires chemical reagents for operation. All analyzes are carried out in a fully automatic manner with a minimum time step of 20 minutes and the possibility of changing it using a remote desktop. In addition, the remote desktop provides a permanent view of the current situation and diagnostics of devices that have been connected to the telemetry system, which enabled the collection of data directly in the IMGW-PIB databases.

The ordered on-line analyzers arrived at the stations in Tczew and Szczecin in the second half of 2016. Due to the fact that the construction of 
the station in Tczew was much more complicated, its construction and final commissioning took place later than in the case of Szczecin.

The first two months of operation of the devices were treated as a start-up during which the operation of the infrastructure, mainly the water sampling system for tests, was checked. Failures in operating the equipment due to weather conditions or power outages, for example, could not be avoided. The station's service in Tczew turned out to be particularly problematic, where the inlet of the pipe used for sampling water to the analyzer became frozen during the winter. Nevertheless, despite these problems, we managed to collect a sufficient amount of data that allowed us to carry out analyzes to date have been impossible to perform, mainly due to the low frequency of measurements performed by the State Environmental Monitoring (SEM).

\section{Description of the area}

Two existing IMGW-PIB stations (hydrometric profiles) located in Szczecin at the Długi Bridge at the Oder estuary to the Stettiner Haff, and Tczew near the estuary of the Vistula to the Baltic Sea were selected for the purpose of analyzing nutrient compounds using on-line analyzers (Fig. 1). Selected hydrometric profiles in Tczew and Szczecin belong to the most important IMGW profiles upon which water status studies are conducted. Until 2015, no studies related to water quality were performed on these profiles.

The hydrometric profile in Tczew is located along $32.8 \mathrm{~km}$ of the river (from its mouth) on the left bank. It covers a catchment area of $193,923 \mathrm{~km}^{2}$. The hydrometric profile is located at the height of the water level profile in the riverbed. In the profile, the river's main channel is one-off. The shore of the left is a natural enough high slope while the right bank is a gentle slope. The flood plain on the right bank is flat and wide, consisting of meadows and wasteland limited by flood embankments.

The hydrometric profile in Szczecin is located along $22.9 \mathrm{~km}$ of the river on the left bank. It covers a catchment with an area of $114986 \mathrm{~km}^{2}$. It is located in the port, where the riverbanks are concreted (retaining wall). These stations have been expanded in such a way that they can be installed within the infrastructure. Both at the station in Szczecin and in Tczew, new water intakes were made allowing to take samples directly from the current. In addition, for the needs of the analyzer installation in Tczew, a well was made that allows it to be installed below ground level with a manhole protecting the analyzer even during flood conditions.

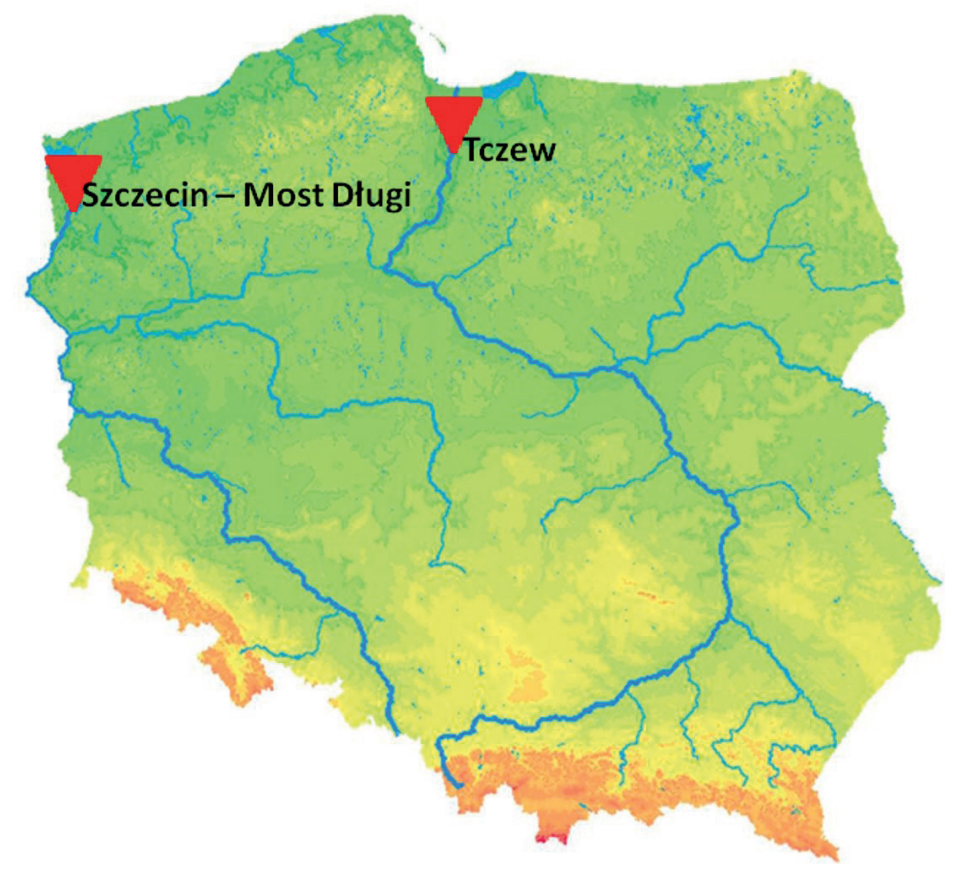

Fig. 1. Location of IMGW-PIB stations equipped with on-line analyzers 


\section{Data}

The period that was taken for analysis for the station in Szczecin began on November 30, 2016 and lasted until August 23, 2017, while for the station in Tczew it began on October 10, 2016 and lasted until August 23, 2017. In truth, this period does not cover the full calendar year, but allows the analysis of TN and TP concentrations and loads transported by two of the main Polish rivers. During the selected period, the analyzers were set up to perform an average of $6 \mathrm{TN}$ and TP concentration determinations per day, although this frequency was changed as needed and technical capabilities of the devices. Due to the fact that the breaks in the operation of the devices could not be avoided, depending on the station for this period of time, a different amount of data is summarized in Tables 1 and 2.

During the period selected for the analysis, there were two interruptions in the operation of the device in the case of the station in Szczecin: from 24.01.2017 to 07.02.2017 and from 09.05.2017 to 06.07.2017. Therefore, the analyzed period in which data was available was divided into three parts (Tab. 1) covering the autumn, winter, spring and summer periods.

In the case of the station in Tczew, there was one break in the operation of the device from $12 / 01 / 2017$ to $03 / 07 / 2017$. Therefore, the analyzed period was divided into two parts (Tab. 2) for which the data were analyzed and covering the autumn and winter period and summer.

For such divided data, the dispersion was calculated, i.e. the variation of the observed values of the variable. The greater it is, the more these values diverge from the central tendency:

$R=\frac{X_{\max }-X_{\min }}{\bar{X}}$

where:

$R$ - data dispersion,

$X_{\max }$ - the maximum value of the measurement,

$X_{\text {min }}$ - the minimum value of the measurement,

$\bar{X}$ - mean value of the measurement.

For each part, the average load and the total load of TP and TN were also calculated in each profile.
Table 1

The amount of data obtained using the on-line analyzer for TN and TP on the calculation profile of Szczecin (the Odra River)

\begin{tabular}{|l|c|c|c|}
\hline \multicolumn{2}{|c|}{ Station of Szczecin } & TN & TP \\
\hline Part I & $30.11 .2016-24.01 .2017$ & 321 & 232 \\
\hline Part II & $07.02 .2017-09.05 .2017$ & 524 & 329 \\
\hline Part III & $06.07 .2017-23.08 .2017$ & 269 & 151 \\
\hline \multicolumn{2}{|c|}{ Total } & $\mathbf{1 1 1 4}$ & $\mathbf{7 1 2}$ \\
\hline
\end{tabular}

\section{Table 2}

The amount of data obtained using the on-line analyzer for TN and TP on the calculation profile of Tczew (the Vistula River)

\begin{tabular}{|l|c|c|c|}
\hline \multicolumn{2}{|c|}{ Station of Tczew } & TN & TP \\
\hline Part I & $10.10 .2016-11.01 .2017$ & 423 & 429 \\
\hline Part II & $04.07 .2017-23.08 .2017$ & 128 & 157 \\
\hline \multicolumn{2}{|c|}{ Total } & 551 & 586 \\
\hline
\end{tabular}

\section{RAC parameter}

$\mathrm{RAC}$ is a parameter that determines the state, surface waters, and measures in order to prevent the deterioration of river water quality. In general, two types of data are needed to calculate the RAC, a limited pollutant load and an actual pollutant load. Limit load (LL) is the maximum load of a selected pollutant that may be in a selected river section of an analyzed river, which has been classified as having class II clean water (good water status). This load was calculated on the basis of the limit concentration (LC), which is determined in Poland by the ordinance of the Minister of the Environment and the selected characteristic flow (CF). Actual load (AL) is the load of a selected pollutant measured at a given time in a selected calculation profile of an analyzed basin. To calculate these pollutant loads, we need to know the concentration of pollutants and the inviolable flow, i.e., the flow of the minimum amount of water needed to maintain biological life in a river. Inviolable flow is used for calculations to provide security buffers for RAC results. Inviolable flow is the least amount of water that has to be in a river to provide optimum conditions for existing ecosystems. This allows the RAC to yield results for surface waters in the event of low flows. 
River absorption capacity RAC for the selected control profile is described with the equation:

$\mathrm{RAC}=\mathrm{LL}-\mathrm{AL}$

where:

LL - limit load for selected pollutant,

AL - actual load for selected pollutant.

Actual load at control profile is described with the equation:

$\mathrm{CL}=\mathrm{AC} \cdot \mathrm{CF}$

where:

AC - actual concentration of selected pollutant,

$\mathrm{CF}$ - inviolable flow (assumed SNQ flow for the calculation profile Szczecin $256 \mathrm{~m}^{3} / \mathrm{s}$, for the calculation profile Tczew $\left.-410.2 \mathrm{~m}^{3} / \mathrm{s}\right)$.
While limit load at control profile is described with the equation:

$\mathrm{LL}=\mathrm{LC} \cdot \mathrm{CF}$

where LC - limit concentration of selected pollutant (maximum value for water quality class II was adopted $-\mathrm{TN}=5 \mathrm{mg} / \mathrm{L}, \mathrm{TP}=0.4 \mathrm{mg} / \mathrm{L}$ ).

From these simple patterns, it can be seen how important it is to select the appropriate inviolable flow and how greatly it affects the final RAC result.

\section{RESULTS}

The Figures $2-5$ show the distribution of TP and TN concentrations along with the division into parts for the two analyzed calculation profiles in Szczecin and Tczew (the Odra River and the Vistula River). In addition, the flow rate values were superimposed on the graph.

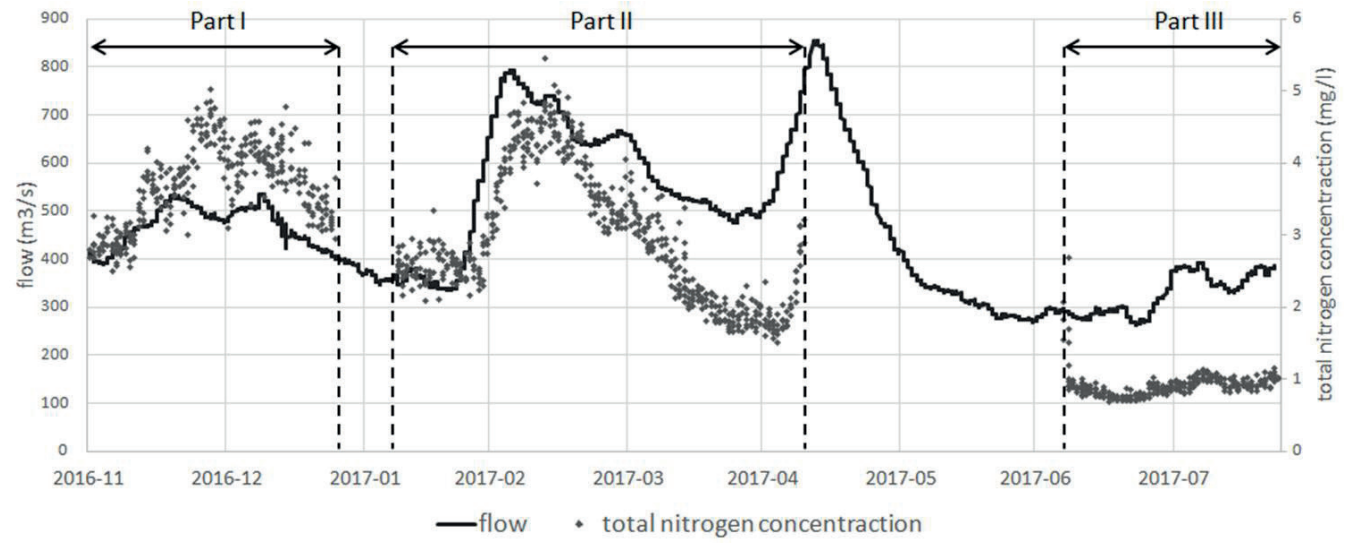

Fig. 2. Distribution of TN pollution concentrations and flow rates for the Odra River in the Szczecin calculation profile

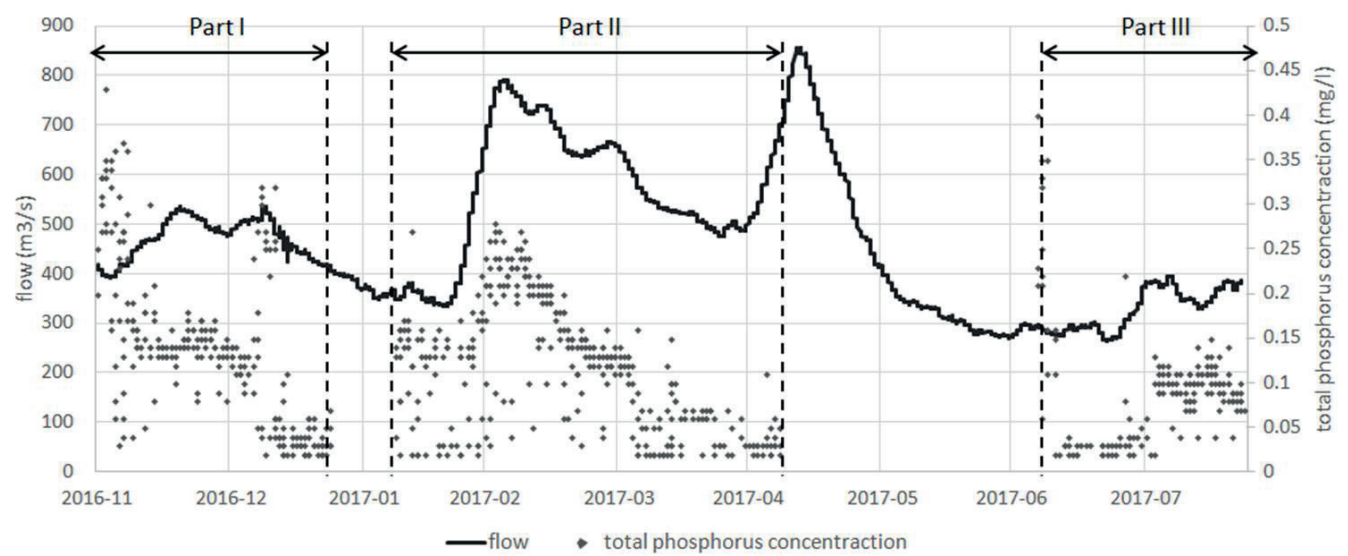

Fig. 3. Distribution of TP pollution concentrations and flow rates for the Odra River in the Szczecin calculation profile 


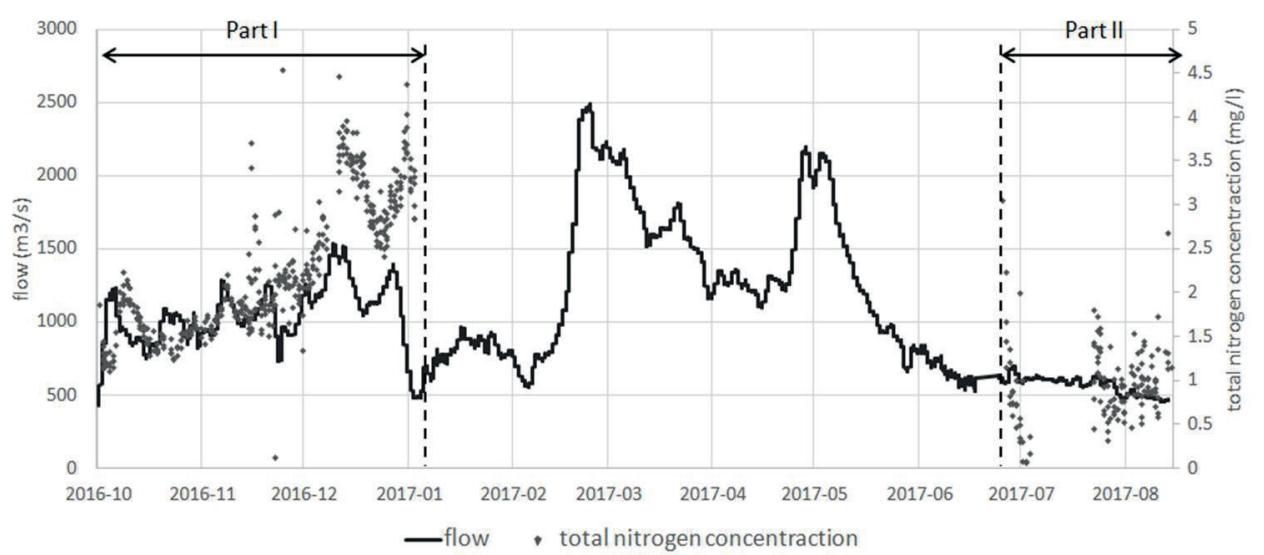

Fig. 4. Distribution of TN pollution concentrations and flow rates for the Vistula River in the Tczew calculation profile

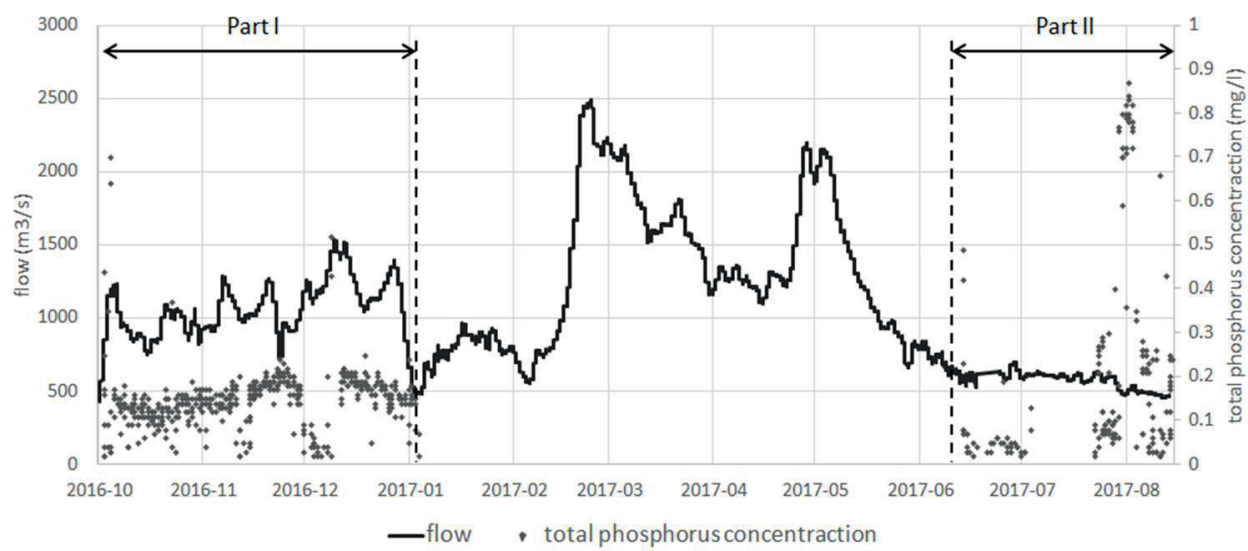

Fig. 5. Distribution of TP pollution concentrations and flow rates for the Vistula River in the Tczew calculation profile

Table 3

Results for the analyzed calculation profiles

\begin{tabular}{|l|l|c|c|c|c|c|c|}
\cline { 3 - 8 } \multicolumn{2}{c|}{} & \multicolumn{3}{c|}{ TN } & \multicolumn{3}{c|}{ TP } \\
\cline { 3 - 8 } \multicolumn{2}{c|}{} & $\begin{array}{c}\text { dispersion } \\
{[\%]}\end{array}$ & $\begin{array}{c}\text { average load } \\
{[\mathbf{t} / \mathbf{d}]}\end{array}$ & $\begin{array}{c}\text { total load } \\
{[\mathbf{t}]}\end{array}$ & $\begin{array}{c}\text { dispersion } \\
{[\%]}\end{array}$ & $\begin{array}{c}\text { average load } \\
{[\mathbf{t} / \mathbf{d}]}\end{array}$ & $\begin{array}{c}\text { total load } \\
{[\mathbf{t}]}\end{array}$ \\
\hline \multirow{3}{*}{$\begin{array}{l}\text { The Odra River } \\
- \text { Szczecin }\end{array}$} & Part I & 68 & 153 & 8493 & 230 & 5.4 & 299 \\
\cline { 2 - 8 } & Part II & 133 & 154 & 13970 & 142 & 5.4 & 485 \\
\cline { 2 - 8 } & Part III & 133 & 27 & 1315 & 344 & 2.2 & 104 \\
\hline $\begin{array}{l}\text { The Vistula } \\
\text { River - Tczew }\end{array}$ & Part I & 122 & 192 & 18052 & 212 & 13 & 1191 \\
\cline { 2 - 8 }$y$
\end{tabular}

Analyzing the results, it is evident that the largest dispersion (of 452\%) was to be found on the Tczew - the Vistula River in the summer for TP (Part II). Also, on the Odra River in the Szczecin profile, the greatest dispersion value for TP was recorded, which reached $344 \%$ in the summer (Part III). TN generally had smaller dispersion values of up to $133 \%$ in the Szczecin profile in the spring and summer
(Part II and Part III) and 298\% in the Tczew profile in Part II (Tab. 3).

The largest average daily loads of both $\mathrm{TN}$ and TP were recorded on the Tczew profile. The average daily value for TP in the autumn and winter months (Part I) was particularly high, at $13 \mathrm{t} / \mathrm{d}$.

Figures 6-9 show the calculated daily values of the RAC parameter for TN and TP for the analyzed calculation profiles on the Vistula and Odra rivers. 


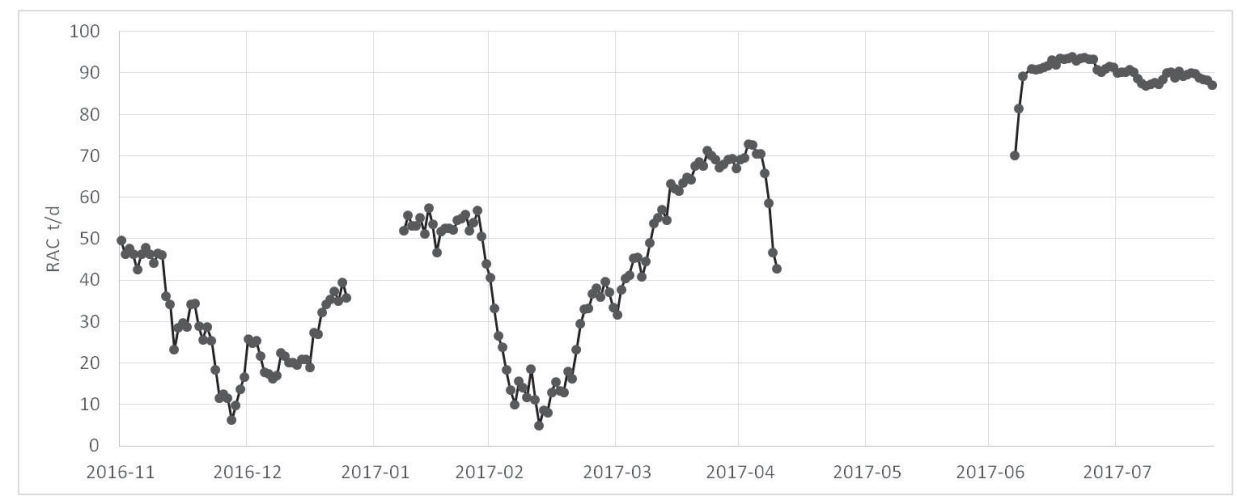

Fig. 6. Daily values of the RAC parameter for TN for the Odra River in the Szczecin profile

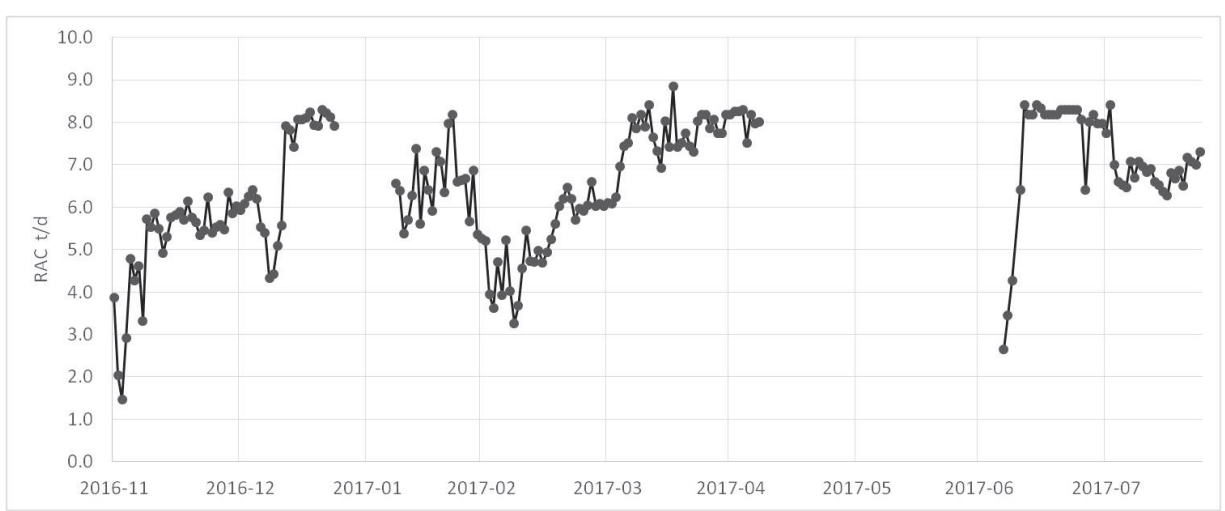

Fig. 7. Daily values of the RAC parameter for TP for the Odra River in the Szczecin profile

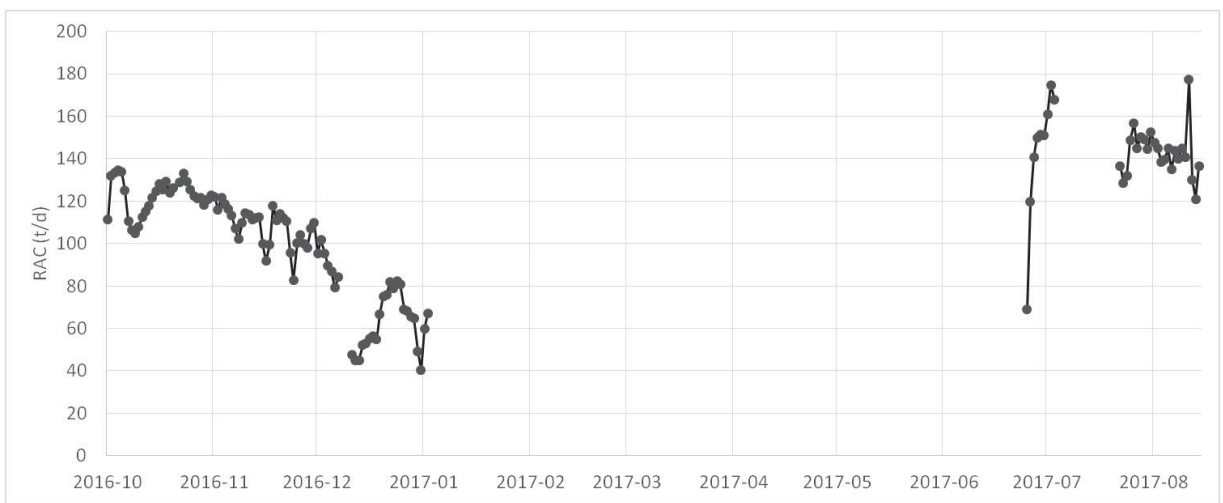

Fig. 8. Daily values of the RAC parameter for TN for the Vistula River in the Tczew profile

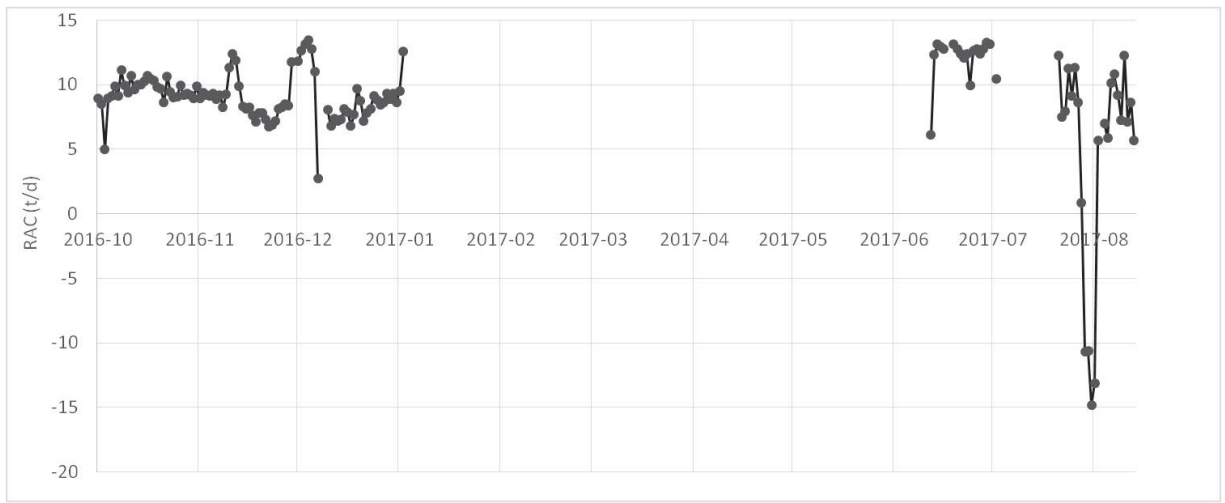

Fig. 9. Daily values of the RAC parameter for TP for the Vistula River in the Tczew profile 
Table 4

Values of the RAC parameter for the calculation profile in Szczecin and Tczew

\begin{tabular}{|c|c|c|c|c|c|c|c|}
\hline & & \multirow{2}{*}{\multicolumn{3}{|c|}{ TN }} & \multirow{2}{*}{\multicolumn{3}{|c|}{ TP }} \\
\hline & & & & & & & \\
\hline & & $\begin{array}{c}\text { average } \\
\text { RAC value } \\
{[t / d]}\end{array}$ & $\begin{array}{c}\text { lowest RAC } \\
\text { value } \\
{[t / d]}\end{array}$ & $\begin{array}{c}\text { highest } \\
\text { RAC value } \\
{[t / d]}\end{array}$ & $\begin{array}{c}\text { average } \\
\text { RAC value } \\
{[t / d]}\end{array}$ & $\begin{array}{c}\text { lowest RAC } \\
\text { value } \\
{[t / d]}\end{array}$ & $\begin{array}{c}\text { highest } \\
\text { RAC value } \\
\text { [t/d] }\end{array}$ \\
\hline \multirow{3}{*}{$\begin{array}{l}\text { The Odra } \\
\text { River - } \\
\text { Szczecin }\end{array}$} & Part I & 28.6 & 6.2 & 49.7 & 5.9 & 1.5 & 8.3 \\
\hline & Part II & 45.3 & 4.9 & 72.8 & 6.6 & 3.3 & 8.8 \\
\hline & Part III & 89.8 & 70.1 & 93.9 & 7.2 & 2.7 & 8.4 \\
\hline \multirow{2}{*}{$\begin{array}{l}\text { The Vistula } \\
\text { River - Tczew }\end{array}$} & Part I & 99.8 & 40.2 & 134.7 & 9.1 & 2.7 & 14 \\
\hline & Part II & 142.8 & 69.1 & 177.2 & 8 & -14.8 & 13.3 \\
\hline
\end{tabular}

For TN in all cases, we have positive values of the RAC parameter on both profiles. The highest mean values of the RAC parameter were recorded in the summer months and the lowest in the winter months. The values of the RAC parameter for TP are slightly different. In the case of the Szczecin calculation profile, the highest average value of the RAC parameter was recorded in the summer months (Part III). In the case of the Tczew calculation profile on the Vistula River, the higher average absorption value was recorded in the autumn and winter months. The average value of the RAC parameter on this profile in the summer months was underestimated as there were days with negative RAC values (Tab. 4).

\section{DISCUSSION}

The results of monitoring carried out on the estuary profiles of the Vistula and Odra basins and their analysis in Poland for the first time made it possible to assess the diurnal and seasonal variability of TN and TP, determining the actual amount of these elements discharged in selected periods to the Baltic Sea based on data generated with a much larger frequency until now. They also allowed us to calculate the RAC parameter, permitting the determination of the state of waters in relation to the water cleanliness class II. Earlier, in the smaller catchments in Poland, IMGW conducted analyzes of the diurnal and seasonal variability of TN and TP, which clearly indicated significant differences between the behavior of these elements in the water environment that may affect the calibration and validation of the environmental mathematical models used. The results presented in the article are not complete for the analyzed period due to problems with on-line analyzers, nevertheless they allow the determination of, how TN and TP load changes in selected periods of the year. Analyzes indicated that these changes can be very large. In the summer months when the self-cleaning processes in the rivers are fully active and the vegetation season of plants in the basin is in progress, there is a significant decrease in TN load in both the Vistula and Odra rivers by $84 \%$ and $83 \%$ respectively as compared to the winter months. In view of the fact that nitrogen in rivers mainly comes from surface runoff from agricultural areas, such large decreases of its load in summer can be explained by the presence of cover plants on the catchment, which are responsible for the so-called flattening phenomenon, consisting of a rapid periodic reduction of nitrogen in surface waters depending on the growing season (Wilk at al. 2017b). Of course, not only plants growing in the basin during the growing season are responsible for such a large drop in the nutrient load of surface waters. Biochemical processes also occur in river waters, transforming pollutants containing mainly organic compounds into simpler compounds with the participation of microorganisms, something which we call the self-purification of the river. The proof of the effectiveness of these processes is a significant reduction of TP load on both the Vistula and Oder rivers by respectively $59 \%$ and $60 \%$.

The article also presents the calculated dispersion values. The very large dispersion values for TP confirms the unique nature of this element and its behavior in the environment. TN in surface waters mostly comes from surface runoff from agricultural areas, while TP enters the water mainly from point sources. TP in surface waters is 
characterized by a much higher hourly, daily and seasonal variability in comparison to TN. Such a large value of TP dispersion is the main reason for problems with the calibration and validation of this parameter in mathematical models. Considering the generally small amount of monitoring data of TN and TP, any research to determine the variability of these elements in small time steps is very important.

Phosphorus in surface waters, unlike nitrogen, mainly comes from point discharges. Therefore, vegetation has a much smaller impact in comparison to TN than in the summer months. In addition, there is a much smaller correlation between the distribution of TP concentrations and the flow rate than in the case of TN. It is much more difficult, or even impossible, to predict the distribution of TP concentration in the profile by having a small database with low frequency measurements.

The total number of days with data for the profile of Szczecin on the Odra River was 194, which accounted for over half the year. During this time, 23,778 tons of TN and 888 tons of TP flowed through this profile. The distribution of pollutant loads in both the analyzed rivers has a direct impact on the results of the calculated RAC parameter. The obtained results of the RAC parameter indicate that the quality of surface water in the two calculation profiles for TN selected for analysis can be described as good. In the case of TP load, it can also be generally stated that the water level on both calculation profiles was good apart from one day for which the RAC parameter value was negative. So, the question arises does Poland contribute large amounts of pollutants to the Baltic as is currently believed? It should be additionally taken into account that some of TN and TP pollution transported by rivers to the Baltic Sea is as a result of a natural background process.

According to HELCOM data, in Poland the value of the natural background concentration for rivers for TN may vary from $0.3 \mathrm{mg} / \mathrm{L}$ to $1.2 \mathrm{mg} / \mathrm{L}$, and for TP it is $0.04 \mathrm{mg} / \mathrm{L}$. This means that the natural pollution background for TN for selected calculation profiles can vary from $11 \%$ to as much as $44 \%$ of the pollutant load, and for TP it can reach up to $40 \%$.

It should also be taken into account that even in the case of rivers where TN and TP loads are significantly exceeded and eutrophication occurs as a consequence, restoring such ecosystems to the ideal reference condition from the past by reducing anthropogenic pressures in many cases may be impossible. The examples show that some ecosystems show very little or no response to the decline in nutrient loads. The directions of changes in ecosystems in relation to the content of nutrients are much more complicated than the simple proportional response of the ecosystem to the selected stimulus (Duarte at al. 2009).

\section{CONCLUSIONS}

- Distribution of TN concentrations, in contrast to $\mathrm{TP}$, in both analyzed calculation profiles is correlated with flow rates;

- TP concentrations are characterized by very high daily variability;

- The values of TN concentrations on both analyzed calculation profiles (Szczecin and Tczew) of the Odra and Vistula catchments remained within the range of values for good water status;

- The values of TP concentrations on the calculation profile Szczecin on the Odra River in all three analyzed parts remained within the range of values for good water status, and on the calculation profile of Tczew on the Vistula River were only negative for one day;

- In most cases, the values of the RAC parameter for TN and TP on both calculation profiles were positive;

- The resulting database can now be used to verify mathematical models, and in the future also to calibrate and validate them, significantly increasing the reliability of simulation results.

\section{REFERENCES}

Abbaspour K.C., Rouholahnejad E., Vaghefi S., Srinivasan R., Yang H. \& Kløve B., 2015. A continental-scale hydrology and water quality model for Europe: Calibration and uncertainty of a high-resolution large-scale SWAT model. Journal of Hydrology, 524, 733-752.

Ahn S.R. \& Kim S.J., 2017. Assessment of integrated watershed health based on the natural environment, hydrology, water quality, and aquatic ecology. Hydrology and Earth System Sciences, 21, 11, 5583-5602.

Ahtiainen H., Artell J., Elmgren R., Hasselström L. \& Håkansson C., 2014. Baltic Sea nutrient reductions - What should we aim for?. Journal of Environmental Management, 145, 9-23. 
Andersen J.H., Carstensen J., Conley D.J., Dromph K., Fleming-Lehtinen V., Gustafsson B.G. \& Murray C., 2017. Long-term temporal and spatial trends in eutrophication status of the Baltic Sea. Biological Reviews, 92(1), 135-149.

Andrulewicz E., 2001. Monitoring środowiska morskiego Bałtyku - rys historyczny (do 2000 r.). Morski Instytut Rybacki w Gdyni, [on-line:] http://docplayer.pl/ 12660129-Monitoring-srodowiska-morskiego-baltyku-rys-historyczny-do-2000-r-eugeniusz-andrulewicz.html.

Duarte C.M., Conley D.J., Carstensen J. \& Sánchez-Camacho M., 2009. Return to Neverland: shifting baselines affect eutrophication restoration targets. Estuaries and Coasts, 32, 1, 29-36.

HELCOM, 2015. Updated Fifth Baltic Sea pollution load compilation (PLC-5.5). Baltic Sea Environment Proceedings, 145, Baltic Marine Environment Protection Commission, Helsinki, [on-line:] http://www.helcom.fi/ Lists/Publications/BSEP145_lowres.pdf.

Ji Z.G., 2017. Hydrodynamics and water quality: modeling rivers, lakes, and estuaries. John Wiley \& Sons.

Kiedrzyńska E., Kiedrzyński M., Urbaniak M., Magnuszewski A., Skłodowski M., Wyrwicka A. \& Zalewski M., 2014. Point sources of nutrient pollution in the lowland river catchment in the context of the Baltic Sea eutrophication. Ecological Engineering, 70, 337-348.

Kundzewicz Z.W., 2001. Water problems of central and eastern Europe-a region in transition. Hydrological Sciences Journal, 46, 6, 883-896.

Loga M., 2016. Wody pod presja. Wydział Instalacji Budowalnych, Hydrotechniki i Inżynierii Środowiska, Politechnika Warszawska, Warszawa.

OstojskiM.S.,2012.Modelowanieprocesówodprowadzaniado Bałtyku związków biogennych: na przykładzie azotu i fosforuogólnego. Wydawnictwo Naukowe PWN, Warszawa.

Ostojski M.S., Gębala J., Orlińska-Woźniak P. \& Wilk P., 2016. Implementation of robust statistics in the calibration, verification and validation step of model evaluation to better reflect processes concerning total phosphorus load occurring in the catchment. Ecological Modelling, 332, 83-93.

Rovira J.L. \& Pardo P., 2006. Nutrient pollution of waters: eutrophication trends in European marine and coastal environments. Contributions to Science, 3, 2, 181-186.

Sapek A., 2008. Źródła substancji wprowadzanych rzekami z Polski do Morza Bałtyckiego. Woda-Środowisko-Obszary Wiejskie, 8, 151-161.

Smith B., Lindeskog M., Engström K., Olin S. \& Poska A., 2016. Robustness and uncertainty in future nutrient loads from land ecosystems across the Baltic Sea catchment area. [in:] Reckermann M. \& Köppen S. (eds.), $1^{\text {st }}$ Baltic Earth Conference Multiple Drivers for Earth System Changes in the Baltic Sea Region: Nida, Curonian Spit, Lithuania, 13-17 June 2016: conference proceedings, International Baltic Earth Secretariat Publication, 9, International Baltic Earth Secretariat, Geesthacht, 59.

Tynkkynen N., Schönach P., Pihlajamäki M. \& Nechiporuk D., 2014. The governance of the mitigation of the Baltic Sea eutrophication: Exploring the challenges of the formal governing system. Ambio, 43, 1, 105-114.

Wilk P., 2015. Metoda obliczania chłonności rzeki jako narzędzie do oceny stanu fizykochemicznego powierzchniowych wód płynacych. IMGW-PIB [Ph.D. Thesis].

Wilk P., Gębala J., Orlińska-Woźniak P. \& Ostojski M., 2016. The importance of hourly nutrient concentration variability in terms of assessment of the surface water state in Słupia Pilot River. Meteorology Hydrology and Water Management. Research and Operational Applications, 4, 13-24.

Wilk P., Orlińska-Woźniak P. \& Gębala J., 2017a. Zmienność stosunku stężeń azotu i fosforu dla wybranych zlewni rzek przymorza. Przegląd Naukowy. Inżynieria i Ksztattowanie Środowiska, 26, 1[75], 55-65.

Wilk P., Orlińska-Woźniak P., Gębala J. \& Ostojski M., 2017b. The flattening phenomenon in a seasonal variability analysis of the total nitrogen loads in river waters. Czasopismo Techniczne, 11, 137-159. 